\title{
Kermit E. McKenzie, 1924-2008
}

A respected historian of Russia and Kazakhstan, Kermit E. McKenzie died of pneumonia on 18 March 2008 at Wesley Woods Hospital in Atlanta, Georgia. Born in 1924 in Hanover County, Virginia, Kermit entered the United States Army in 1943 and fought with the 9th infantry division (47th regiment) in the European theater, rising to the rank of sergeant and being awarded two purple hearts. Following the war, he received his BA from the University of Richmond in 1947, his MA in 1949, and his PhD in history in 1960 from Columbia University. In 1947, he also completed a program at the Russian Institute in Moscow. Kermit taught Russian and Soviet history at Emory University in Atlanta from 1960 until 1995. Conversant in at least four languages, while reading several more, Kermit both advocated and embodied the success that can come from a good education. As the author of Comintern and World Revolution, 1928-1943: The Shaping of Doctrine (1963), editor of Fedor Rodichev's Vospominaniia i ocherki o russkom liberalizme (1983) and the author of an unfinished manuscript about the brilliant Kazakh ethnographer Chokan Valikhanov, as well as the author of eight peer-reviewed articles and many briefer scholarly notes, Kermit constantly strove to expand his scholarly horizons. A gifted teacher, Kermit directed sixteen doctoral dissertations and served his department as chair from 1982 to 1987 and his profession with many positions on leading professional organizations such as the American Association for the Advancement of Slavic Studies and the Southern Conference on Slavic Studies. Kermit was also a true southern gentleman - brilliant but humble, he rarely spoke ill of others. He loved his country but not always its policies. In 1967, Kermit took an early stance against the Vietnam War. Not only did he oppose U.S. intervention, he spoke out to "counter the ridiculous and profoundly anti-democratic notion that participation in warfare imposes a moratorium on free and critical inquiry respecting the rightness or wrongness of that participation." A proud, lifelong liberal, Kermit always cheered for the underdog and the little guy, and his contributions to his students and colleagues were unstinting.

Matthew Payne Emory University April 2008

\section{Edward Carl Thaden, 1922-2008}

Edward C. Thaden, professor emeritus of history at the University of Illinois, Chicago, died on 9 July 2008 in Seattle, Washington, after a long illness. Trained in the traditions of European historical scholarship, Thaden was a cosmopolitan in his mastery of sources in the major and some minor languages of the continent, which he read to remain current on the latest scholarship in his field, and he conveyed that tradition to his students even as the requirement for language study steadily declined in history doctoral programs. He infected his students with a passion for the serious, critical study of history. A pioneer in the field of Slavic studies, Thaden leaves behind a body of professional publications that serves as a testament to his influence on that field and on the larger ones of European intellectual history, the integration of imperial Russia's western borderlands, and historiography. An erudite scholar of broad interests, Thaden established close ties with an extensive community of American and European historians engaged in the study of the history of the Slavs, culminating in his presidency of the Commission Internationale des Etudes Historiques Slaves in 1995-2000. At the same time, he was one of the pioneers of the interdisciplinary approach to the development of Slavic area studies in the United States and served as executive director of the American Association for the Advancement of Slavic Studies from 1982 to 1984. In the wake of the Twentieth Party Congress of the Communist Party of the Soviet Union in 1956, Thaden was one of the first American historians to establish professional contacts with Soviet scholars, and his observations contributed to the climate that promoted research opportunties for young and senior American 